\title{
A-GIS Based Risk Assessment Approach for Evaluating Shelters in Crisis Areas: Case of Idleb/Syria
}

\author{
Jamil Hallak ${ }^{1}$, Melik Koyuncu ${ }^{2}$, Pınar Özkurt ${ }^{3 *}$ \\ 1* Dr Industrial Engineer, Gaziantep, Turkey (ORCID: 0000-0001-5975-4075), jamil.hallak@ southwales.ac.uk

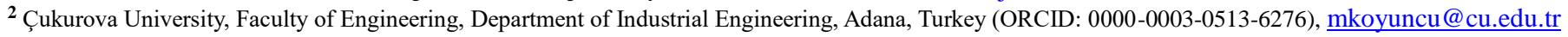 \\ ${ }^{3}$ Tarsus University, Faculty of Economics and Administrative Sciences, Department of Management Information Systems, Tarsus, Turkey (ORCID: 0000-0002-9655- \\ 0319), pinarozkurt@tarsus.edu.tr
}

(First received 10 October 2021 and in final form 25 December 2021)

(DOI: 10.31590/ejosat.1007768)

ATIF/REFERENCE: Hallak, J., Koyuncu, M. \& Özkurt, P. (2021). A GIS-Based Risk Assessment Approach for Evaluating Shelters in Crisis Areas: Case of Idleb/Syria. European Journal of Science and Technology, (31), 837-851.

\begin{abstract}
Millions of people escaped the country, and numerous individuals were displaced since the crisis in Syria started on March 15, 2011. Particularly, internally displaced persons confront troubles in the sense of shelter and housing requirements. The aim of this paper is to propose a new approach for risk assessment in selecting shelters at humanitarian context in crisis areas by employing real data from the region. We included conducting risk assessment in crisis areas, identifying the risks/criteria using the Delphi technique, prioritizing risks using Interval Type-2 Fuzzy Analytic Hierarchy Process (IT2F-AHP), and finally selecting the shelters with lower risk values. For this purpose, we created risk maps for each individual risk/criterion by employing the Geographic Information System (GIS) and merged the risks' maps into a single final risk map by overlaying them utilizing the weights produced from F-AHP to discover the complete risk value for each area in the study region. Lastly, we extracted and ranked the final risk values for the shelters to enable the decision maker to consider the lower-risk value shelters, as it can aid in expediting and facilitating the housing solutions at times of disasters and crisis.
\end{abstract}

Keywords: Syria Crisis, Risk Assessment, Delphi Technique, Shelter, IT2F-AHP (Interval Type-2 Fuzzy Analytic Hierarchy Process), Geographic Information System (GIS).

\section{Kriz Alanlarında Sığınakları Değerlendirmek için CBS'ye Dayalı Bir Risk Değerlendirme Yaklaşımı: İdlib/Suriye'de Uygulama}

Öz

Suriye'deki kriz 15 Mart 2011'de başladığından beri milyonlarca insan ülkeden kaçmıştır ve çok sayıda birey yerlerini değiştirmiştir. Özellikle, ülke içinde göç etmek zorunda kalmış insanlar sığınak ve barınma açısından zorluklarla karşılaşmaktadır. Bu çalışmanın amacı, bölgeden gerçek veriyi kullanarak, kriz alanlarında insani yardım kapsamında sığınakları seçmenin risk değerlendirmesi için yeni bir yaklaşım önermektir. Çalışmaya; kriz alanlarında risk değerlendirmesi yürütme, Delphi tekniği ile riskleri/kriterleri belirleme, Aralık Tip-2 Bulanık Analitik Hiyerarşi Prosesi (IT2F-AHP) kullanarak riskleri önceliklendirme ve son olarak düşük risk değerlerine sahip sığınakları seçme dâhil edilmiştir. Bu amaçla, Coğrafi Bilgi Sistemi’ni (CBS) kullanarak her risk/kriter için risk haritaları oluşturulmuştur ve çalışma bölgesindeki her alanın son risk değerini bulmak için, Bulanık AHP'den elde edilen ağırlıklardan faydalanarak ve risk haritaları örtüştürülerek tek bir nihai risk haritasına dönüştürülmüştür. Son olarak, afet ve kriz zamanlarındaki barınma çözümlerini kolaylaştırabileceği ve hızlandırabileceğinden dolayı, karar vericinin düşük risk değerli sığınakları göz önünde bulundurmasını sağlamak için, sığınakların nihai risk değerleri bulunmuş ve sığınaklar sıralanmıştır.

Anahtar Kelimeler: Suriye Krizi, Risk Değerlendirme, Delphi Tekniği, Sığınak, Aralık Tip-2 Bulanık Analitik Hiyerarşi Prosesi, Coğrafi Bilgi Sistemi (CBS).

\footnotetext{
* Corresponding Author: pinarozkurt@ tarsus.edu.tr
} 


\section{Introduction}

An individual or a group of individuals, who have been compelled or obligated to run away or set off their homes/rooted locations, particularly in consequence of or on the purpose of refraining from the harmful impacts of armed conflict, circumstances of generalised brutality, disregards of human rights, natural or artifactitious disasters, and have not crossed over an internationally recognised border, are termed as "internally displaced people" (IDPs) (Inee Toolkit, 2019). According to United Nations High Commissioner for Refugees (UNHCR), the estimated number of IDPs worldwide is approximately 36 million at present, and approximately 3 million of these individuals are looking for asylums. Of the 36 million IDPs, about $16 \%$ belong to Syria only. These numbers are increasing every twenty minutes due to ongoing wars in several countries. The grim reality about IDPs is that it is difficult to reach them, and unfortunately, they are not preserved by a specific status (Bilak et al., 2015). As a result of these circumstances, IDPs are among the most defenseless people in the world today (UNHCR, 2019). Since they lack education in a land with cultural and religious diversities, their living conditions are caustic. Hence, they encounter considerable obstacles to fulfil their needs, just as accession to foodstuffs, water, shelter, and health services. Furthermore, mortality rate in complicated emergencies is estimated to be the highest among IDPs when in comparison with those among the occupants or migrants with refugee status (Heudtlass et al., 2016).

As Syria hosts more than $15 \%$ of IDPs worldwide, this subject requires a considerable emphasis. The reason for higher number of IDPs in Syria is the Syrian Crisis, which started out on March 2011 at Daraa city in the southwestern part of the country. It is considered one of the most complicated and dynamical humanitarian crisis in the world. The spread and intensification of conflicts has led to a dire humanitarian crisis with approximately 6.3 million IDPs and approximately 4.5 million people live in hard-to-reach and encircled regions, as pointed out by the UNHCR. Over half of the citizens has been forced to leave their houses, and many individuals have been moved several times. Furthermore, children and young person constitute more than half of the displaced people. Ongoing conflicts; which render the settlements, hospitals, and trade centers dysfunctional, are the fundamental reasons of internal migration. Of the 6.3 million IDPs in all Syrian governorates; 908,929 IDPs belong to the Idleb governorate, which represents approximately $15 \%$ of the total number of IDPs and this situation is ranked to be the second after Rural Damascus.

Thus, Idleb governorate plays a significant role in the current situation. Before conducting studies to devise permanent solutions for this humanitarian situation, obtaining real data by analyzing the region's circumstances is of capital importance.

However, to best of our knowledge, there is no systematic statistics that contains the real data about target areas in crisis regions, such as Idleb/Syria. Therefore, in the light of all the factors discussed so far, the objective of this study is to handle one of the crisis area's survival problems using the risk assessment aspect from the humanitarian perspective and bridging the gaps in the related subject by serving as an effective source for similar problems. We focused on determining shelters in Idleb based on the risk factors. For this purpose, we presented a novel method that ranks all the candidate shelters according to their risk value using a Geographic Information System (GIS) - based risk assessment. For the risk evaluation, we utilized the Delphi method to discover the potential risks in an ongoing conflict area and then prioritized the risks by applying a Fuzzy Analytic Hierarchy Process (F-AHP). For identifying the risks, we collected the real data from the specific area using beneficiaries and direct stakeholders. The data obtained are projected in GIS as geographic layers and all the identified risks are merged in the final layer to procure the final risk map. The method constituted the shelter risk ranking, which aided us in determining the shelters based on their final risk values. These points are the motive that makes this study valuable contribution in determining the available shelters for IDPs in the conflict area. To this end, our contributions, compared to existing literature can be summarized as indicated below:

- First of all, the proposed approach provides a beneficial procedure to decision makers for assaying and selecting the shelters based on risk assessment.

- Secondly, the proposed approach is applicable in crisis areas for obtaining the best possible solutions from a humanitarian perspective and providing solutions for IDPs' housing issues.

- Thirdly, it depicts the possibility of analyzing a multi-criteria decision-making methodology with GIS techniques using real-time data and fuzzy logic.

- Last but not the least, the proposed approach can be used by any institution or authority in conflict contexts.

The remaining of this paper is organised in this way: in the Section 2, we represent a literature review with a short summary of the related studies; in Section 3, we propose the risk assessment approach employed in this study; Section 4 demonstrates the case study results with risk maps generated by the GIS and finally Section 5 summarizes the discussions about this study and presents suggestions for further studies.

\section{Literature Review}

In this study, we handle a risk assessment approach with GIS for shelter location problem. In literature, we encountered various aspects which indicated that none of the studies matched our topic entirely. Several studies suggested risk assessment approaches in conflict areas (Mock et al., 2004; Burnley et al., 2008; Yu and Lee, 2012). While one of the studies proposed a systematic approach to conduct a domestic armed conflict risk assessment in any part of the world by constructing a statistical model (Burnley et al., 2008; another presented a framework for risk assessment with the aim of preventing the human immunodeficiency 
virus in conflict-affected surroundings in Africa (Mock et al., 2004). Yu and Lee (2012) concentrated on an urban reformation project and organized a conflict-risk evaluation model based on Fuzzy Failure Mode and Effect Analysis (Fuzzy-FMEA).

However, any study did not address risk assessment via GIS in a conflict area. Particularly in humanitarian areas, it is not sufficient to only optimize the shelter's locations to include as many individuals as possible; it is also important to ensure that the risks in these shelters are relatively low. This enables the process of selecting the available shelters with lower risk levels and alleviating the misery of IDPs within that specific crisis area. At this point, Geographic
Information System (GIS) can handle and analyze large scale spatial data efficiently (Zhang et al., 2017; Çeliker et al., 2019; Karimi et al., 2019).

Therefore, the GIS platform, which is a valuable resource for such studies, is required to project all the risk values and criteria corresponding to the target area on maps, analyze all the risk criteria, and then extract the output values from maps to each of the candidate shelters. It is observed that the GIS is applied widely in literature for humanitarian solutions for risk assessment. The summary of GIS-based Risk Assessment Studies containing utilized approach and problem area are presented by Table 1 below.

Table 1. Summary of GIS-Based Risk Assessment Studies

\begin{tabular}{|c|c|c|}
\hline Author(s) & Approach & Problem Area \\
\hline Huabin et al. (2005) & $\begin{array}{l}\text { GIS Based Landslide Hazard } \\
\text { Assessment }\end{array}$ & $\begin{array}{l}\text { The state of the art of landslide hazard evaluation } \\
\text { focusing GIS-based techniques }\end{array}$ \\
\hline Abdalla et al. (2006) & $\begin{array}{l}\text { GIS, Digital Evaluation Model (DEM), } \\
\text { Digital Terrain Model (DTM) }\end{array}$ & $\begin{array}{l}\text { Evaluating flood risk of the Qu'Appelle River, Southern } \\
\text { Saskatchewan, Canada }\end{array}$ \\
\hline Fedeski and Gwiliam (2007) & GIS, Vulnerability Index & $\begin{array}{l}\text { Developing a risk assessment methodology for flood and } \\
\text { geological hazards and applying in Lewes, Sussex, UK }\end{array}$ \\
\hline Wang et al. (2011) & $\begin{array}{l}\text { GIS, Spatial Multi Criteria Decision } \\
\text { Analysis (SMCA) }\end{array}$ & $\begin{array}{l}\text { Flood Risk Evaluation in the Dongting Lake Region, } \\
\text { China }\end{array}$ \\
\hline Beni et al. (2012) & GIS, Spatio-Temporal Analysis & $\begin{array}{l}\text { Assessing food safety risks in Canadian food distribution } \\
\text { organizations }\end{array}$ \\
\hline Uddin et al. (2013) & GIS, Remote Sensing & $\begin{array}{l}\text { Identifying flood hazard zones and flood shelters in Sindh } \\
\text { Province, Pakistan }\end{array}$ \\
\hline Alcorn et al. (2013) & GIS, Multi-Criteria Evaluation & $\begin{array}{l}\text { Volcanic hazard and risk evaluation of eruptions in Valles } \\
\text { Caldera, New Mexico, USA }\end{array}$ \\
\hline Abdalla et al. (2014) & $\begin{array}{l}\text { GIS, Three-Dimensional Fuzzy Risk } \\
\text { Assessment, Hydro, Statistical } \\
\text { Simulation }\end{array}$ & $\begin{array}{l}\text { Measuring the flood risk evaluation at the Red River in } \\
\text { Southern Manitoba, Canada }\end{array}$ \\
\hline Sarkar et al. (2016) & $\begin{array}{l}\text { GIS, Remote Sensing, Fuzzy-based Risk } \\
\text { Assessment Model (FRAM) }\end{array}$ & $\begin{array}{l}\text { Specifying the areas with varying intensity of wetland } \\
\text { conversion risk in East Kolkata Wetland Area, India }\end{array}$ \\
\hline Aye et al. (2016) & GIS, Web Based Tool & $\begin{array}{l}\text { Analyzing the impacts and consequences of a certain } \\
\text { hazard event in the Fella River basin, Italy }\end{array}$ \\
\hline Çankaya et al. (2016) & $\begin{array}{l}\text { GIS, Multi-Criteria Decision Analysis, } \\
\text { AHP }\end{array}$ & Tsunami risk evaluation in Yenikapı, İstanbul, Turkey \\
\hline Zhao and Liu (2016) & GIS, Regional Risk Assessment & $\begin{array}{l}\text { Evaluating regional urban major hazards in urban district } \\
\text { of northern China }\end{array}$ \\
\hline Chen et al. (2017) & GIS, Disaster Risk Analysis & $\begin{array}{l}\text { Urban emergency shelter system for natural disasters in } \\
\text { Guangzhou, China }\end{array}$ \\
\hline Şentürk and Erener (2017) & GIS, Multi Criteria Analysis, AHP & $\begin{array}{l}\text { Determining temporary shelter areas in natural disasters } \\
\text { for Gölcük, Turkey }\end{array}$ \\
\hline Al-Awadhi et al. (2018) & GIS, Flood Hazard Maps & $\begin{array}{l}\text { Assessing flooding risk analysis for Muscat, Sultanate of } \\
\text { Oman }\end{array}$ \\
\hline Isahak et al. (2018) & GIS, Flood Disaster Risk Map & $\begin{array}{l}\text { Delineating risk zones and evaluating shelter centers for } \\
\text { Pahang River, Malaysia }\end{array}$ \\
\hline Rincon et al. (2018) & GIS, Multi Criteria Analysis (AHP) & $\begin{array}{l}\text { Developing updated and accurate flood risk maps in } \\
\text { Greater Toronto Area, Canada }\end{array}$ \\
\hline Chen et al. (2018) & GIS, Spatial Distribution & $\begin{array}{l}\text { Selecting urban resources and allocating for emergency } \\
\text { shelters in Guangzhou, China }\end{array}$ \\
\hline Repetto et al. (2018) & GIS, Web Based Platform & $\begin{array}{l}\text { Assessing complex structural and infrastructural systems' } \\
\text { risk for wind exposure }\end{array}$ \\
\hline Sahoo and Bhaskaran (2018) & GIS, Multi Hazard Risk Assessment & $\begin{array}{l}\text { Risk assessment of coastal vulnerability from typical } \\
\text { cyclones in Odista coast, India }\end{array}$ \\
\hline
\end{tabular}




\begin{tabular}{|c|c|c|}
\hline Lyu et al. (2018) & GIS, AHP, Interval AHP (I-AHP) & $\begin{array}{l}\text { Flood risk assessment in the Guangzhou metro system, } \\
\text { China }\end{array}$ \\
\hline Pence et al. (2019) & $\begin{array}{l}\text { GIS, Level } 3 \text { Probabilistic Risk } \\
\text { Assessment (PRA) }\end{array}$ & $\begin{array}{l}\text { Advancing emergency preparedness, planning, and } \\
\text { response for severe nuclear power plant accidents in Surry } \\
\text { Power Station, USA }\end{array}$ \\
\hline Cai et al. (2019) & $\begin{array}{l}\text { GIS, Multi-Index Fuzzy Comprehensive } \\
\text { Evaluation Model }\end{array}$ & $\begin{array}{l}\text { Analyzing flood disaster risk in the urban area of Yifeng, } \\
\text { Jiangxi Province, China. }\end{array}$ \\
\hline Eccles et al. (2019) & GIS, Spatial Analysis & $\begin{array}{l}\text { Evaluating spatial ecological risk in Athabasca Oil Sands } \\
\text { Area, Canada }\end{array}$ \\
\hline Zhang et al. (2019) & GIS, Hazards that Create Risk & $\begin{array}{l}\text { Increasing tsunami shelter accessibility in Nagoya city, } \\
\text { Japan }\end{array}$ \\
\hline Benguerai et al. (2019) & GIS, Remote Sensing & Forest fire risk assessment in Northwest Algeria \\
\hline Shalyari et al. (2019) & GIS, Monte Carlo Simulation & $\begin{array}{l}\text { Health risk evaluation of nitrate in groundwater resources } \\
\text { of Iranshahr, Iran }\end{array}$ \\
\hline Gallego et al. (2019) & GIS, PROMETHEE, AHP & $\begin{array}{l}\text { Risk assessment for livestock production in Valencian } \\
\text { Community (VC), Spain }\end{array}$ \\
\hline Skilodimou et al. (2019) & GIS, Multi-Criteria Analysis, AHP & $\begin{array}{l}\text { Multi hazard assessment for natural hazards in Peneus } \\
\text { (Pinios) River, Greece }\end{array}$ \\
\hline Gao et al. (2019) & $\begin{array}{l}\text { GIS, AHP, Fuzzy Theory, Pollutant } \\
\text { Diffusion Model }\end{array}$ & $\begin{array}{l}\text { Regional water ecosystem risk assessment in Shenzhen } \\
\text { eco-industrial park, China }\end{array}$ \\
\hline Hawchar et al. (2020) & GIS, High Level Risk Analysis & $\begin{array}{l}\text { Assessing climate change risk of critical infrastructure in } \\
\text { Ireland }\end{array}$ \\
\hline Yariyan et al. (2020) & $\begin{array}{l}\text { GIS, Fuzzy AHP, Artificial Neural } \\
\text { Networks }\end{array}$ & $\begin{array}{l}\text { Evaluating the extent of earthquake vulnerability in } \\
\text { Sanandaj, Iran }\end{array}$ \\
\hline Hadipour et al. (2020) & $\begin{array}{l}\text { GIS, Spatial Multi-Criteria Decision } \\
\text { Analysis (SMCA), AHP }\end{array}$ & $\begin{array}{l}\text { Providing a coastal flood risk assessment approach and } \\
\text { implementation in Bandar Abbas City, Iran }\end{array}$ \\
\hline Zhang et al. (2020) & GIS, Spatial Multi-Index Model & Flood risk assessment in the Yangtze River Basin, China \\
\hline Ak et al. (2020) & $\begin{array}{l}\text { GIS, Spatial Decision Support System } \\
\text { (SDSS) }\end{array}$ & $\begin{array}{l}\text { Analyzing hazardous materials transportation risk in } \\
\text { Istanbul, Turkey }\end{array}$ \\
\hline Török et al. (2020) & GIS, Risk Based Quantitative Approach & $\begin{array}{l}\text { Evaluating territorial compatibility for Seveso-type sites } \\
\text { in Oltchim Chemical Plant, Romania }\end{array}$ \\
\hline Psomiadis et al. (2020) & GIS Based Multi Criteria Analysis, AHP & $\begin{array}{l}\text { Landslide susceptibility and risk evaluation in the Basin } \\
\text { of the Sperchios River, Greece }\end{array}$ \\
\hline
\end{tabular}

As seen from Table 1, the framework of GIS-based risk assessment studies varies. For example, while some studies focused on climate change risk assessment (Hawchar et al., 2020), ecological risk assessment (Eccles et al., 2019) or food safety risk assessment (Beni et al., 2012); some papers handled the related topic for natural disasters. In this context, some studies concentrated on multiple disasters (Chen et al., 2017; Chen et al., 2018); however, there are risk assessment researches on earthquake (Yariyan et al., 2020), fire (Benguerai et al., 2019), landslide (Huabin et al., 2005; Aye et al., 2016; Psomiadis et al., 2020), tropical cyclone (Sahoo and Bhaskaran, 2018), tsunami (Çankaya et al., 2016) and volcanic hazard (Alcorn et al., 2013). Still, it is observed that majority of existing studies concentrated on utilizing GIS for flood risk assessment (Abdalla et al., 2006; Fedeski and Gwilliam, 2007; Wang et al., 2011; Uddin et al., 2013; Abdalla et al., 2014; Aye et al., 2016; Al-Awadhi et al., 2018; Isahak et al., 2018; Rincón et al., 2018; Lyu et al., 2018; Cai et al., 2019; Hadipour et al., 2020; Zhang et al, 2020).

However, to the best of our knowledge, six of the studies integrated GIS and risk assessment to resolve the shelter issues (Uddin et al., 2013; Chen et al., 2017; Şentürk and Erener, 2017; Isahak et al., 2018; Chen et al., 2018; Zhang et al., 2019) (Table 1). But, application of these studies was limited to natural disasters.

Therefore, this study is motivated by the fact that it is important to determine shelter locations, particularly in conflict areas, based on the risk factors related to the conflict. As indicated by the literature review, no studies have addressed the shelter locations in crisis areas by integrating the risk assessment process from the humanitarian perspective. Other distinguishing features of this study are the introduction of a novel approach based on GIS and application of the Delphi method and F-AHP for determining the possible risks and prioritizing the related risks, respectively.

\section{Material and Method}

\subsection{Risk Assessment Approach}

In this section, we present a risk assessment approach starting from collecting the related data to calculating the risk parameters for identifying the final risk for each shelter. Figure 1 presents the approach proposed in this study for assessing the risks in the targeted area and choosing the shelter locations based on it. As shown in Figure 1, the 
proposed approach was primarily based on risk assessment in the conflict areas using: Delphi technique to identify the criteria according to the beneficiaries lived in the affected area; Interval Type-2 Fuzzy AHP to handle uncertainty while calculating the weights of each criteria (since we are utilizing opinions and words which mean different evaluations/values to different experts) and GIS to draw the related maps to each criterion and overlapping all maps to find out the final risk map. The proposed approach included six basic stages (Figure 1):

1. Collecting Data: A needs assessment was conducted using surveys and interviews to assess the needs and understand the context in the study region with respect to considered factors, criteria, and related risks from the perspectives of direct beneficiaries and local authorities. The data about Idleb were drawn from direct beneficiaries and key informants across all 26 sub-districts in the Idleb governorate. For this case study, relevant data were collected between January 03, 2019 and March 22, 2019.

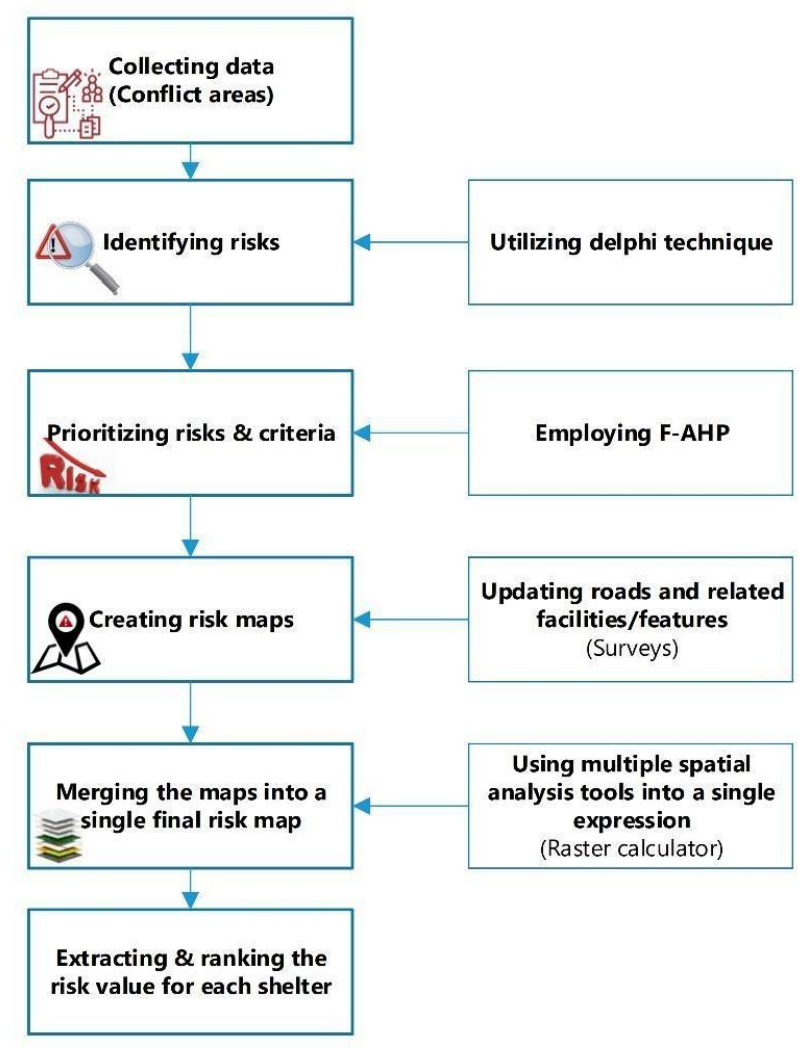

Figure 1. Flowchart of the Proposed Methodology

2. Identifying Risks Using the Delphi Technique: All of the decision makers do not live in the same location and therefore, they possess various points of view about the topic. However, it is essential to achieve a consensus on the identification of risks related to determining the shelters. Due to the previous reasons and to allow experts express their views and opinions in an individual and anonymous way and to access other experts' views as the process, the Delphi technique is utilized. By this tool, we combine 3 dedicated expert's opinions from different areas and contexts to help and influence the identification. It is a collaborative method for building consensus between specialists and includes independent investigation and voting by the specialists. Throughout this tool, every expert can define the risks without the effect of other experts on his/her opinion.

In this paper we have two types of criteria; the first one is crisp/non-spatial criteria which is determined by crisp value and not related to spatial data such as the cost and number of IDPs. The second type is spatial criteria which is related to the spatial data such as the closeness from frontlines or main roads.

We deal with these two types from the risk perspective and we handle the crisp type as a risk for example the higher cost corresponds to the higher risk and the lower cost corresponds to the lower risk. Then we reflect this information on the map to study all criteria from the maps perspective and solve the problem by the GIS tool to facilitate the process of selecting shelters in such a crisis context for the people in the area; instead of utilizing highadvance mathematical software which is not available right now for local authorities in the crisis area.

As a result, criteria/risks are defined in the study and categorized as described in Figure 2.

3. Prioritizing Risks and Criteria Using Interval Type-2 Fuzzy AHP: In this stage, the risks/criteria were arranged in a hierarchical structure and evaluated by the 3 dedicated experts from various points of view. The relative importance of each criterion was determined using linguistic variables and the uncertainty was obtained by presenting interval type2 trapezoidal membership function.

4. Creating Risk Maps: After updating/collecting the related spatial data for each risk identified in Stage (2), the maps were generated for each criterion/risk as below:

- Building and updating the roads network using GIS;

- Facility locations, for instance schools and hospitals, to classify the study region according to the real distance from these facilities;

- Features of shelters, such as the capacity and setup costs.

A risk map was created by classifying the areas, which demonstrate the areas from the lower risk throughout the high-risk areas. Each identified risk is classified under one of the six classes according to experts (on a scale of 1-6 with 1 being/having the lowest risk and 6 being/having the highest risk). As shown in Figure 2, the risks are divided under three categories: (i) Criteria that affect the implementation of humanitarian actors as these actors/organizations conduct projects in the crisis area, the risks need to be analyzed from their perspectives. (ii) Criteria affecting the civilian population, as they have been 
suffering from the crisis more than eight years and are the direct beneficiaries. (iii) Criteria that affect the both categories (i) and (ii).

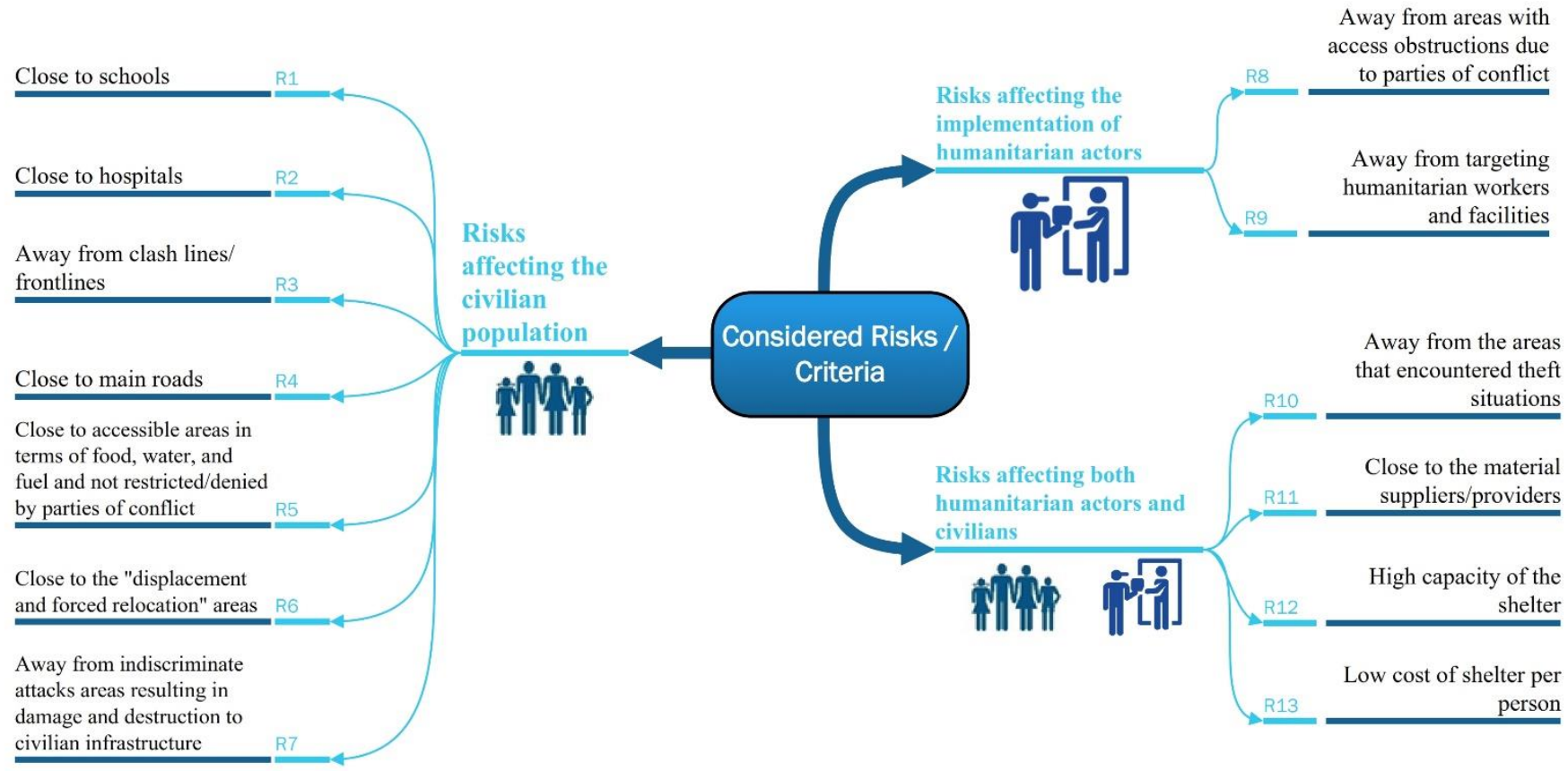

Figure 2. Risks and Categories Utilized in the Study

5. Merging the Risks Maps into a Single Final Risk Map: After building different risk maps, a single final risk map was created by overlaying maps using the weights calculated in Stage (3) to find out the complete risk value of each area in the study location. Equation (1) below is used to compute the final risk value by multiplying each risk/criteria weight by the respective risk value and then obtaining the sum of the all of the products calculated. This was performed using the GIS package (ArcMap 10.4.1).

$$
F R V=\sum_{n \in N} R W_{n} R V_{n}
$$

where $\mathrm{N}$ is the set of risk map/layer $(\mathrm{n} \epsilon \mathrm{N}), \mathrm{FRV}$ is the final risk value, RW is the risk weight calculated using the IT2F$\mathrm{AHP}$, and RV is the risk value of each criterion in the area.

6. Extracting and Ranking the Final Risk Value for Shelters: In this stage, we extracted the final risk value for each shelter in the area according to the shelter's location in the final risk map obtained from Stage (5). Then, we ranked them ascendingly from low to high-risk values to enable the decision makers to consider the shelters with lower-risk values.

\subsection{Prioritizing Risks Using Fuzzy Analytical Hierarchy Process (F-AHP)}

Using Interval Type-2 Fuzzy AHP, the goal and criteria were arranged in a hierarchical structure and evaluated by experts. The comparative importance of each criterion was specified using linguistic variables, which were represented as trapezoidal interval type-2 fuzzy scales as shown in Figure 3 where for linguistic variable there is upper trapezoidal membership function (-U) and Lower trapezoidal membership function (-L). In this study, The Defuzzified Triangular Type-2 Fuzzy Set (DTtrT) method (Kahraman et al., 2014) is utilized to convert the fuzzy evaluations into their corresponding crisp values.

A 5-point scale was utilized to describe the relative significance of criterion with regard to the others as summarized in Table 2 and graphically in Figure 3.

Fuzzy comparison matrix $\mathrm{A}^{\tilde{r}}$ representing the fuzzy relative importance of each pair elements is defined by Equations (2) and (3) below (Öztayşi, 2015): 
$\widetilde{\mathrm{A}}=\left[\begin{array}{cccc}1 & \tilde{\mathrm{a}}_{12} & \ldots & \tilde{\mathrm{a}}_{1 \mathrm{n}} \\ \tilde{\mathrm{a}}_{21} & 1 & \ldots & \tilde{\mathrm{a}}_{2 \mathrm{n}} \\ \vdots & \vdots & \ddots & \vdots \\ \tilde{\mathrm{a}}_{\mathrm{n} 1} & \tilde{\mathrm{a}}_{\mathrm{n} 2} & \ldots & 1\end{array}\right]=\left[\begin{array}{cccc}1 & \tilde{\mathrm{a}}_{12} & \ldots & \tilde{\mathrm{a}}_{1 \mathrm{n}} \\ 1 / \tilde{\mathrm{a}}_{12} & 1 & \ldots & \tilde{\mathrm{a}}_{2 \mathrm{n}} \\ \vdots & \vdots & \ddots & \vdots \\ 1 / \tilde{\mathrm{a}}_{1 \mathrm{n}} & 1 / \tilde{\mathrm{a}}_{2 \mathrm{n}} & \ldots & 1\end{array}\right]$

$1 / \widetilde{a}_{12}=\left[\begin{array}{l}{\left[\frac{1}{a_{14}^{U}}, \frac{1}{a_{13}^{U}}, \frac{1}{a_{12}^{U}}, \frac{1}{a_{11}^{U}} ; H_{1}\left(a_{12}^{U}\right), H_{2}\left(a_{13}^{U}\right)\right],} \\ {\left[\frac{1}{a_{24}^{L}}, \frac{1}{a_{23}^{L}}, \frac{1}{a_{22}^{L}}, \frac{1}{a_{21}^{L}} ; H_{1}\left(a_{22}^{L}\right), H_{2}\left(a_{23}^{L}\right)\right]}\end{array}\right]$

The geometric mean method is applied to get the fuzzy geometric mean $r_{i}$ with Equation 4 given below (Öztayşi, 2015):

$$
\tilde{r}_{i}=\left(\tilde{a}_{i 2} \times \tilde{a}_{i 2} \times \ldots \times \tilde{a}_{i n}\right)^{\frac{1}{n}}
$$

The fuzzy weight $\widetilde{w}_{i}$ of the $i$.th criterion is computed with Equation 5 given below (Öztayşi, 2015):

$$
\widetilde{w}_{i}=\tilde{r}_{i} \times\left(\tilde{r}_{1}+\tilde{r}_{2}+\cdots+\tilde{r}_{n}\right)^{-1}
$$

Table 2. Interval Type-2 Fuzzy Scales for Pairwise Comparison (Öztayşi, 2015)

\begin{tabular}{ll}
\hline Linguistic variables & $\begin{array}{l}\text { Trapezoidal Interval Type-2 fuzzy } \\
\text { scales }\end{array}$ \\
\hline Absolutely Strong (AS) & $(7,8,9,9 ; 1,1)(7.2,8.2,8.8,9 ; 0.8,0.8)$ \\
Very Strong (VS) & $(5,6,8,9 ; 1,1)(5.2,6.2,7.8,8.8 ; 0.8,0.8)$ \\
Fairly Strong (FS) & $(3,4,6,7 ; 1,1)(3.2,4.2,5.8,6.8 ; 0.8,0.8)$ \\
Slightly Strong (SS) & $(1,2,4,5 ; 1,1)(1.2,2.2,3.8,4.8 ; 0.8,0.8)$ \\
Exactly Equal (E) & $(1,1,1,1 ; 1,1)(1,1,1,1 ; 1,1)$ \\
\hline
\end{tabular}

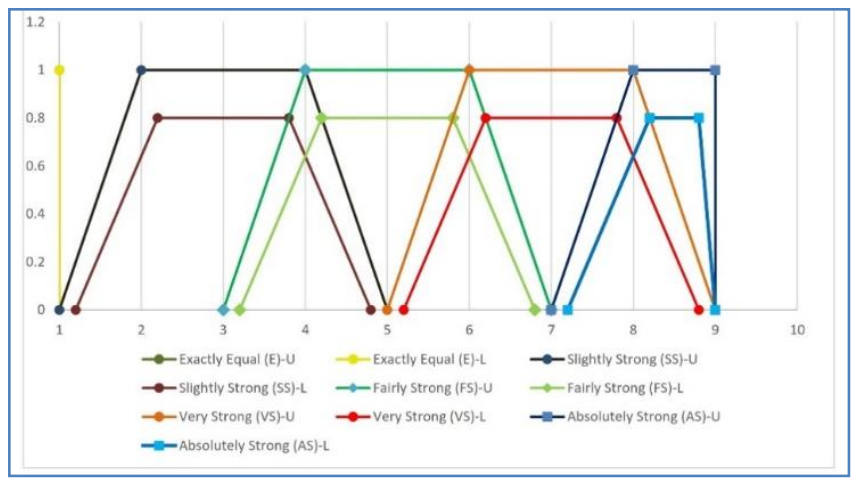

Figure 3. Fuzzified Scale Type 2 for Pairwise Comparison

Table 3 lists the weights obtained using interval type-2 fuzzy AHP in this paper which shows risks criteria are prioritized and ranked from 1 to 13 .

Table 3. Weights Obtained from Interval Type-2 Fuzzy AHP

\begin{tabular}{clcc}
\hline $\begin{array}{c}\text { Risk } \\
\text { No. }\end{array}$ & Fuzzy Weights $\widetilde{W}_{i}$ & $\begin{array}{c}\text { Normalized } \\
\text { Weight }(\mathbf{N W})\end{array}$ & $\begin{array}{c}\text { Risk Ranking } \\
\text { (From 1 to 13) }\end{array}$ \\
\hline R1 & $(0.11,0.17,0.32,0.45 ; 1,1)(0.12,0.18,0.3,0.42 ; 0.8,0.8)$ & 0.02 & 10 \\
\hline R2 & $(0.09,0.14,0.27,0.39 ; 1,1)(0.1,0.15,0.25,0.36 ; 0.8,0.8)$ & 0.03 & 9 \\
\hline R3 & $(0.07,0.1,0.21,0.33 ; 1,1)(0.07,0.11,0.2,0.3 ; 0.8,0.8)$ & 0.22 & 1 \\
\hline R4 & $(0.05,0.08,0.16,0.26 ; 1,1)(0.06,0.09,0.15,0.23 ; 0.8,0.8)$ & 0.01 & 13 \\
\hline R5 & $(0.04,0.06,0.12,0.2 ; 1,1)(0.04,0.06,0.11,0.18 ; 0.8,0.8)$ & 0.09 & 5 \\
\hline R6 & $(0.03,0.05,0.1,0.16 ; 1,1)(0.04,0.05,0.09,0.14 ; 0.8,0.8)$ & 0.07 & 6 \\
\hline R7 & $(0.02,0.03,0.07,0.11 ; 1,1)(0.02,0.04,0.06,0.1 ; 0.8,0.8)$ & 0.05 & 7 \\
\hline R8 & $(0.02,0.02,0.05,0.08 ; 1,1)(0.02,0.03,0.04,0.07 ; 0.8,0.8)$ & 0.15 & 3 \\
\hline R9 & $(0.01,0.02,0.04,0.07 ; 1,1)(0.01,0.02,0.04,0.06 ; 0.8,0.8)$ & 0.19 & 2 \\
\hline R10 & $(0.01,0.01,0.03,0.04 ; 1,1)(0.01,0.01,0.03,0.04 ; 0.8,0.8)$ & 0.03 & 8 \\
\hline R11 & $(0.01,0.01,0.02,0.03 ; 1,1)(0.01,0.01,0.02,0.03 ; 0.8,0.8)$ & 0.01 & 12 \\
\hline R12 & $(0.01,0.01,0.01,0.02 ; 1,1)(0.01,0.01,0.01,0.02 ; 0.8,0.8)$ & 0.01 & 11 \\
\hline R13 & $(0,0.01,0.01,0.01 ; 1,1)(0,0.01,0.01,0.01 ; 0.8,0.8)$ & 0.12 & 4 \\
\hline
\end{tabular}

\section{Case Study and Results}

\subsection{Case Study}

We have applied proposed methodology to a crisis area in Idleb, Syria for our case study since this area contains the highest number of IDPs in need to shelter housing solutions. This is carried on by applying the methodology defined in the Material and Method Section.
The Idleb governorate is located in the northwest of Syria and has a border with Turkey. Its total size is $6,097 \mathrm{~km}^{2}$ and has approximately $1,464,000$ person (this number is 2010 prediction, because due to ongoing crisis in the country, there is not any updated population prediction).

In the preparation process of this study, an evaluation is performed in the study region. Within this evaluation, our aim was specifying and assessing the condition of shelters, IDPs, and 


\section{Avrupa Bilim ve Teknoloji Dergisi}

related factors in the target area. Figure 4 demonstrates the pattern of IDPs and nominee shelters corresponding to the location-allocation problem addressed in this study.

The data about the study area's characteristics, such as the capacity, costs of setup, and IDPs are collected by conducting surveys and interviews in coordination with the authorities in the area (local councils and civil community organizations). A total of 331 nodes are incorporated in the study. Moreover, 51 nominee shelters with varied capacities, costs, and distances from the frontlines/clashes, hospital, and schools are also taken into consideration for the study.

Authorities in the region are facing so many difficulties in terms of finding the most suitable candidate shelters to allow the most vulnerable IDPs who are living in random cluster of makeshifts, cramped tents to move to those selected shelters which have better circumstances (built by concrete/bricks and contain an operating kitchen, bathroom) to improve their lives, give them privacy and dignity. Before this approach, the selection of shelters and IDPs was utilized by a non-systemically approach, according to decision of local authorizes and sometimes without any transparency to beneficiaries in the area.

Thus, in this study, each service facility, such as a school, hospital or shelter is determined by its longitude and latitude. Afterwards, a road network dataset is built and definitions of the classes of area according to the distance from this service facility are realized. For instance, Class 1 defined the area within a distance of $1 \mathrm{~km}$ from the school, and Class 2 defined the area within a distance of $2 \mathrm{~km}$ from the school. This definition is continued until the distance between the area and service facility was higher than $10 \mathrm{~km}$. All the classes corresponding to each criterion are listed in Table 4. These definitions were obtained based on the interviews/surveys with experts and key stakeholders in each field. This approach provided the desired values to be used in the classification of each risk/criterion. In this process, the experts and key stakeholder agreed on making 6 categories to classifying the risks in humanitarian context. We employed the Natural Break (Jenks) classification method for this

purpose.

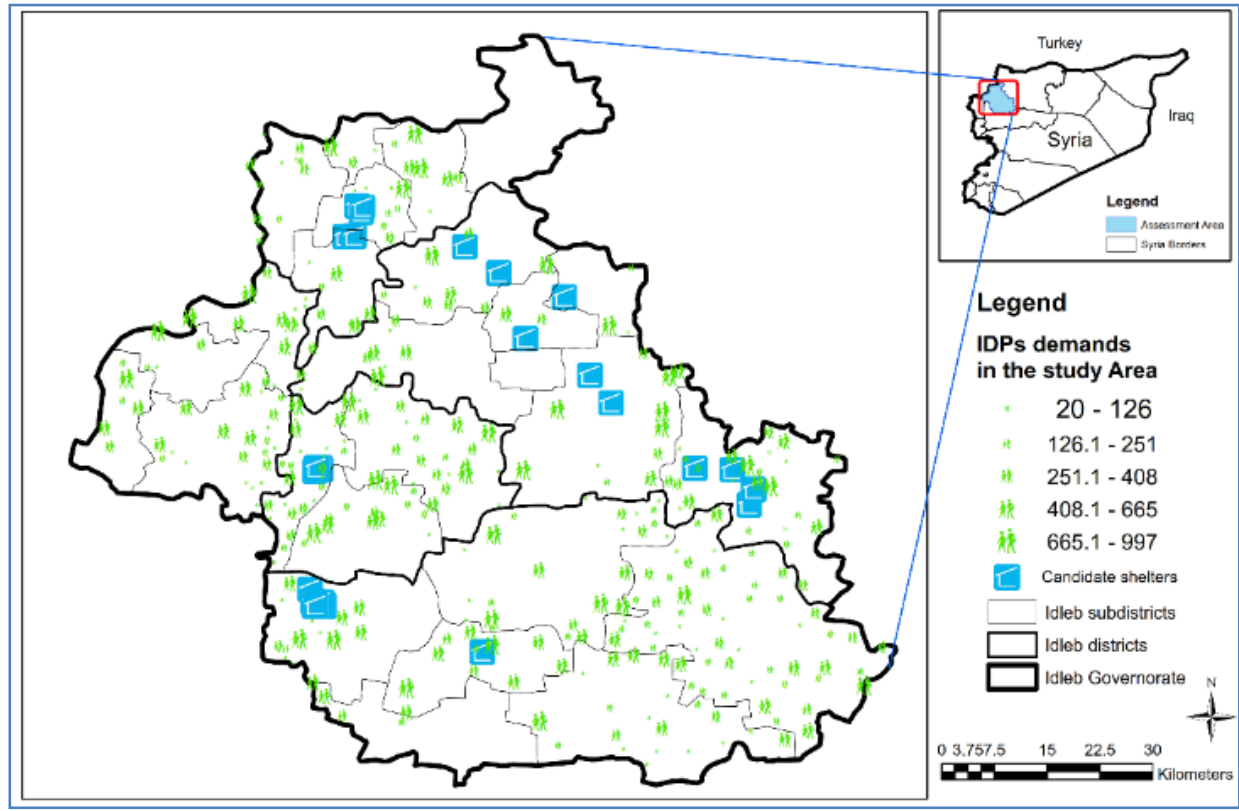

Figure 4. Overview About Displacement and Candidate Shelters in Idleb, Syria

Table 4. Risk Classifications for Each Identified Risk in the Study

\begin{tabular}{ll}
\hline $\begin{array}{l}\text { Risk } \\
\text { No. }\end{array}$ & $\begin{array}{l}\text { Risk classification } \\
\text { 6 classes: from class } 1 \text { (low risk) through class } 6 \text { (high risk) }\end{array}$ \\
\hline R1 & $\begin{array}{l}\text { 1 - low risk: Located within a region of } 5 \mathrm{~km} \text { from schools } \\
\text { 6 - high risk: Located in a region } 10 \mathrm{~km} \text { away from schools }\end{array}$ \\
\hline R2 & $\begin{array}{l}\text { 1 - low risk: Located within a region of } 5 \mathrm{~km} \text { from hospitals } \\
\text { 6 - high risk: Located in a region } 50 \mathrm{~km} \text { away hospitals }\end{array}$ \\
\hline R3 & $\begin{array}{l}\text { 1 - low risk: Located within a region of } 5 \mathrm{~km} \text { from frontlines } \\
\text { 6 - high risk: Located in a region } 10 \mathrm{~km} \text { away from frontlines }\end{array}$ \\
\hline R4 & $\begin{array}{l}\text { 1 - low risk: Located within a region of } 5 \mathrm{~km} \text { from main roads } \\
\text { 6 - high risk: Located in a region } 10 \mathrm{~km} \text { away from main roads }\end{array}$ \\
\hline R5 & $\begin{array}{l}\text { 1 - low risk: fully accessible } \\
\text { - high risk: fully besieged }\end{array}$ \\
\hline R6 & $\begin{array}{l}\text { 1 - low risk: number of IDPs is more than } 7824 / \mathrm{km}^{2} \text { in the area surveyed } \\
6 \text { - high risk: number of IDPs is less than } 1505 / \mathrm{km}^{2} \text { in the area surveyed }\end{array}$ \\
\hline
\end{tabular}




\begin{tabular}{|c|c|}
\hline R7 & $\begin{array}{l}1 \text { - low risk: no incident reports were issued about indiscriminate attacks during the last year in the area } \\
\text { surveyed } \\
6 \text { - high risk: more than } 10 \text { incident reports were issued about indiscriminate attacks during the last year } \\
\text { in the area surveyed }\end{array}$ \\
\hline R8 & $\begin{array}{l}1 \text { - low risk: no incident reports were issued about access obstructions during the last year in the area } \\
\text { surveyed } \\
6 \text { - high risk: more than } 10 \text { incident reports were issued about access obstructions during the last year in } \\
\text { the area surveyed }\end{array}$ \\
\hline R9 & $\begin{array}{l}1 \text { - low risk: no incident reports were issued about targeting humanitarian workers and facilities during } \\
\text { the last year in the area surveyed } \\
6 \text { - high risk: more than } 10 \text { incident reports were issued about targeting humanitarian workers and } \\
\text { facilities during the last year in the area surveyed }\end{array}$ \\
\hline R10 & $\begin{array}{l}1 \text { - low risk: no incident reports were issued about areas encountered theft situations during the last year } \\
\text { in the area surveyed } \\
6 \text { - high risk: more than } 10 \text { incident reports were issued about areas encountered theft situations during } \\
\text { the last year in the area surveyed }\end{array}$ \\
\hline R11 & $\begin{array}{l}1 \text { - low risk: Located within a region of } 5 \mathrm{~km} \text { from vendors' locations } \\
6 \text { - high risk: Located in a region } 50 \mathrm{~km} \text { away from vendors' locations }\end{array}$ \\
\hline R12 & $\begin{array}{l}1 \text { - low risk: shelter capacity is within } 679-989 \text { individuals } \\
6 \text { - high risk: shelter capacity is within } 40-90 \text { individuals }\end{array}$ \\
\hline R13 & $\begin{array}{l}1 \text { - low risk: setup costs of } 22-34 \$ / \text { person in the candidate shelter } \\
6 \text { - high risk: setup costs } 94.1-135 \$ / \text { person in the candidate shelter }\end{array}$ \\
\hline
\end{tabular}

Figure 5, 6, 7, 8 below show the top four prioritized risks according to IT2F-AHP results obtained from Table 3 . These risk maps can be described respectively as follows: away from clash lines; away from the area that targets humanitarian workers; away from access obstructions by parties of conflict and shelters' setup costs [\$/person].

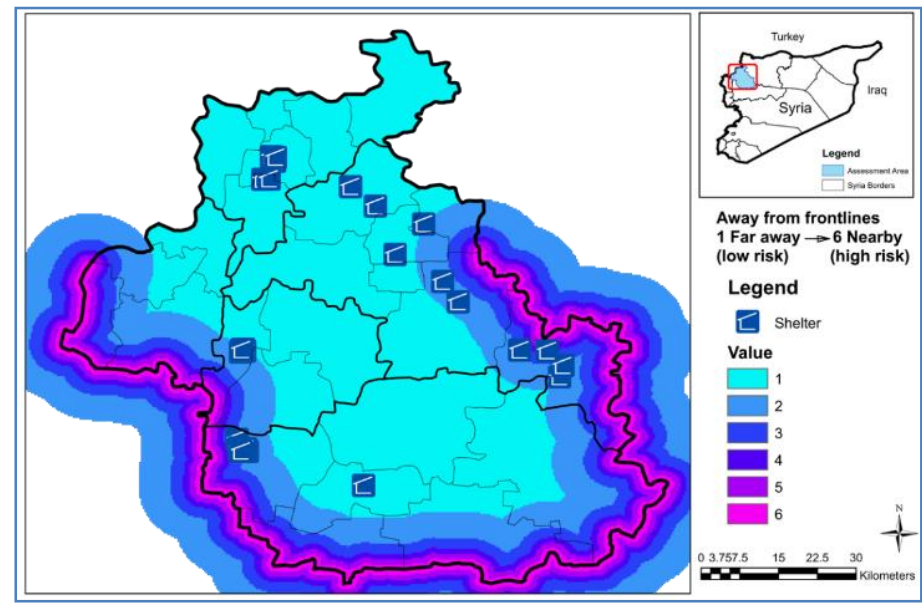

Figure 5. Risk Map: Away from Clash Lines/Frontlines in Idleb, Syria

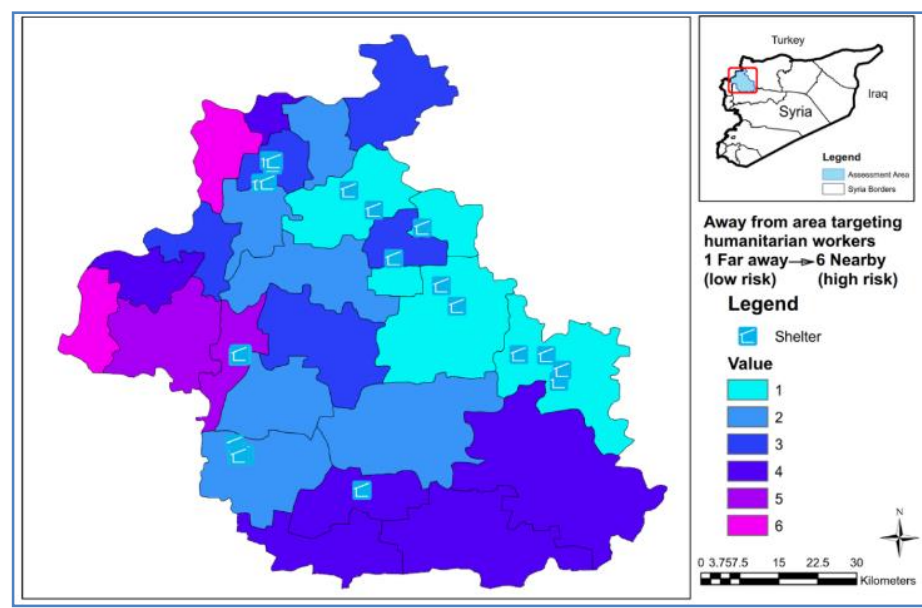

Figure 6. Risk Map: Away from the Area Targeting Humanitarian Workers 


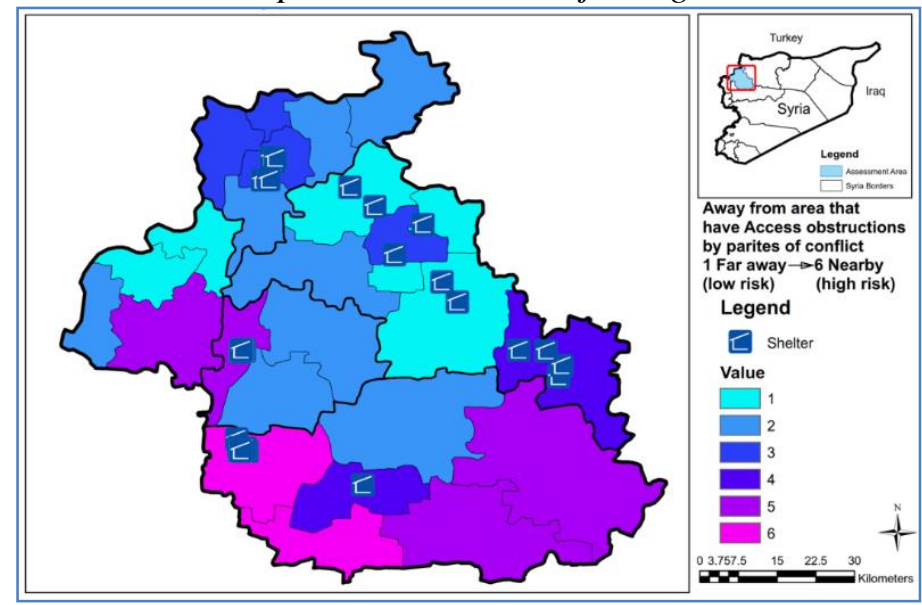

Figure 7. Risk Map: Obstructions by Parties of Conflict

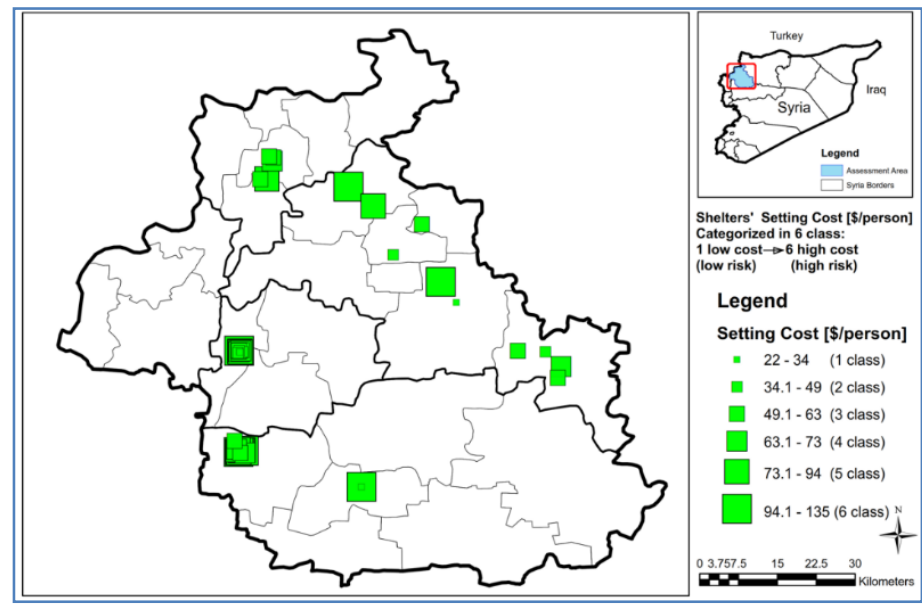

Figure 8. Risk Map: Shelters'Setup Costs

The other risks according to their risk rankings are included in Appendix 1: accessibility to food, water, and fuel; proximity to displacement and forced relocation areas; indiscriminate attacks resulting in damage and destruction; away from the areas of theft; proximity to hospitals, proximity to schools, shelters' capacity [persons], proximity to venders/suppliers; and proximity to main roads that serves the area.

\subsection{Results}

In this section we considered the risk weight in each criterion utilizing the IT2F-AHP as calculated in Table 3. As well, the risk value in each region in the target study area is evaluated and then we utilized the Equation 1 to obtain the final risk value/map in each region. In the final map, all the risk maps are merged and overlapped into a final risk map, as demonstrated in Figure 9.

This map is described as follows:

- Each region is colored according to its risk value from 1.260 (lower risk regions) to 4.654 (higher risk regions)

- As the shelters are located in the final risk map, we projected the shelter coordinates on the final map to acquire the risk value for each shelter which vary from 1.662 (lower risk) to 3.594 (higher risk).

- While there are six risk category areas ranging approximately from $1.1260-4.6540$, the risk value for each shelter varies from 1.126-3.594. We can observe that there is no shelter located in the highest risk area (darkest red one) and therefore, there are no shelters within the highest risk value.

- Some of the shelters are so adjacent to each other as shown in Figure 9 in groups $\mathrm{A}, \mathrm{B}$, and $\mathrm{C}$ (distances between them are less than $1 \mathrm{~km}$ ). We

can observe that the risk values within those located in the same group are approximately similar, because most risk criteria are based on the region features perspective.

- The more criteria we involve the more varied values we obtain. This results in higher variance between the shelters, which facilitates the selection process for the decision makers.

Table 5 defines the risk values of different shelters and the related ranking to facilitate the decision makers. The lower risk value shelters are more favor for the crisis areas since it takes into account the factor considered by affected people such as to be closer to the services like hospitals, schools, main roads and etc. and avoid the dangers of being closer to frontlines, thief areas, being in besieged areas and etc. as well facilitating the works of humanitarian actors implementing such as projects in the conflict areas. 


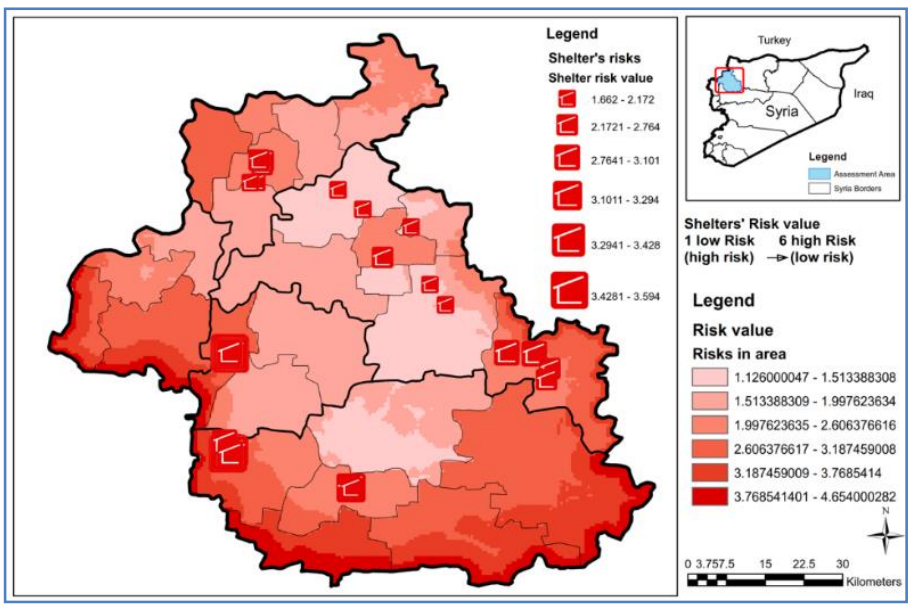

Figure 9. Risk Map: Shelters' Final Risk Value

Table 5. Risk Values and Rankings of Shelters

\begin{tabular}{ccc|ccc|cccc}
\hline $\begin{array}{c}\text { Shelter } \\
\text { No. }\end{array}$ & $\begin{array}{c}\text { Shelter risk } \\
\text { value }\end{array}$ & $\begin{array}{c}\text { Shelter } \\
\text { ranking }\end{array}$ & $\begin{array}{c}\text { Shelter } \\
\text { No. }\end{array}$ & $\begin{array}{c}\text { Shelter } \\
\text { risk value }\end{array}$ & $\begin{array}{c}\text { Shelter } \\
\text { ranking }\end{array}$ & $\begin{array}{c}\text { Shelter } \\
\text { No. }\end{array}$ & $\begin{array}{c}\text { Shelter risk } \\
\text { value }\end{array}$ & $\begin{array}{c}\text { Shelter } \\
\text { ranking }\end{array}$ \\
\hline SH1 & 3.04 & 19 & SH18 & 3.38 & 38 & SH35 & 3.09 & 21 \\
SH2 & 3.14 & 25 & SH19 & 3.22 & 30 & SH36 & 3.26 & 33 \\
SH3 & 3.14 & 26 & SH20 & 3.18 & 28 & SH37 & 2.66 & 12 \\
SH4 & 2.94 & 16 & SH21 & 2.74 & 13 & SH38 & 2.76 & 14 \\
SH5 & 3.38 & 37 & SH22 & 3.29 & 35 & SH39 & 3.00 & 17 \\
SH6 & 3.42 & 42 & SH23 & 3.50 & 48 & SH40 & 2.83 & 15 \\
SH7 & 3.26 & 31 & SH24 & 3.28 & 34 & SH41 & 1.66 & 1 \\
SH8 & 3.14 & 27 & SH25 & 3.51 & 49 & SH42 & 1.70 & 2 \\
SH9 & 3.01 & 18 & SH26 & 3.49 & 47 & SH43 & 2.01 & 6 \\
SH10 & 3.12 & 24 & SH27 & 3.59 & 51 & SH44 & 2.42 & 10 \\
SH11 & 3.36 & 36 & SH28 & 3.39 & 40 & SH45 & 1.98 & 5 \\
SH12 & 3.53 & 50 & SH29 & 3.09 & 20 & SH46 & 1.70 & 3 \\
SH13 & 3.42 & 43 & SH30 & 3.40 & 41 & SH47 & 2.54 & 11 \\
SH14 & 3.49 & 46 & SH31 & 3.10 & 22 & SH48 & 2.36 & 8 \\
SH15 & 3.43 & 44 & SH32 & 3.19 & 29 & SH49 & 2.38 & 9 \\
SH16 & 3.43 & 45 & SH33 & 3.38 & 39 & SH50 & 1.97 & 4 \\
SH17 & 3.26 & 32 & SH34 & 3.10 & 23 & SH51 & 2.17 & 7 \\
\hline
\end{tabular}

\section{Conclusions}

In this study, we introduced a new approach that can aid the decision makers in the crisis areas to identify optimal shelter locations by performing the risk scoring of each candidate shelter in terms of the most important factor to the affected people in the target area.

This study mainly included the definition of the most important criteria according to beneficiaries and their representative, experts, and the donors utilizing the Delphi

technique. Then the agreed criterions are prioritized using the FAHP followed by assessing the risks in all areas according to each agreed criterion and merging all the risk maps into a final risk map using the weights derived from F-AHP. The final risk value is then obtained for each shelter by extracting the risk value of shelters from the final risk map.

As a result, we ranked all the 51 shelters according to their final risk scores considering the predetermined criteria from the humanitarian perspective in crisis regions. This can enable the decision maker in selecting the shelters effectively.

However, the study demonstrates a number of restrictions. Firstly, the study region is restricted to north of Syria, and locations are assessed with 13 risk criterions from crisis and humanitarian perspectives. Furthermore, the study is restricted in dealing with static/stable situation in the studied area. To address these drawbacks, future studies can incorporate the recommendations below: 


\section{Avrupa Bilim ve Teknoloji Dergisi}

- Exclusive of the 13 noted risk criteria, different criterion (such as electricity, water, parks, and social services) could be considered.

- Collecting data on smaller areas (at community level rather than at sub-district level) may provide finer details and produce more accurate values.

- Instead of a static approach, a dynamic one can be proposed to deal with the high-level uncertainness of these kind of questions in crisis regions.

- The study region can be widened to extend the investigation for more extensive results.

- Different risk techniques can be utilized to obtain varied results.

\section{References}

Abdalla, R., Tao, C. V., Wu, H., \& Maqsood, I. (2006). A GISsupported 3D approach for flood risk assessment of the Qu'Appelle River, Southern Saskatchewan. International Journal of Risk Assessment and Management, 6(4-6), 440455. https://doi.org/10.1504/IJRAM.2006.009545

Abdalla, R., Elawad, Y., Chen, Z., Han, S. S., \& Xia, R. (2014). A GIS-supported fuzzy-set approach for flood risk assessment. Canadian Water Resources Journal/Revue canadienne des ressources hydriques, 39(1), 3-14.

https://doi.org/10.1080/07011784.2014.881058

Ak, R., Bahrami, M., \& Bozkaya, B. (2020). A time-based model and GIS framework for assessing hazardous materials transportation risk in urban areas. Journal of Transport \& Health, 19, 100943. https://doi.org/10.1016/j.jth.2020.100943

Al-Awadhi, T., Charabi, Y., Choudri, B. S., \& Bani Oraba, Y. (2018). Flooding risk analysis: A case study of Muscat Governorate, Sultanate of Oman. Human and Ecological Risk Assessment: An International Journal, 24(3), 667-678. https://doi.org/10.1080/10807039.2017.1396441

Alcorn, R., Panter, K. S., \& Gorsevski, P. V. (2013). A GISbased volcanic hazard and risk assessment of eruptions sourced within Valles Caldera, New Mexico. Journal of volcanology and geothermal research, 267, 1-14.

https://doi.org/10.1016/j.jvolgeores.2013.09.005

Aye, Z. C., Jaboyedoff, M., Derron, M. H., Van Westen, C. J., Hussin, H. Y., Ciurean, R. L., ... \& Pasuto, A. (2016). An interactive web-GIS tool for risk analysis: a case study in the Fella River basin, Italy. Natural Hazards and Earth System Sciences, 16(1), 85-101. https://doi.org/10.5194/nhess-16-85-2016

Benguerai, A., Benabdeli, K., \& Harizia, A. (2019). Forest Fire Risk Assessment Model Using Remote Sensing and GIS Techniques in Northwest Algeria. Acta Silvatica et Lignaria Hungarica: An International Journal in Forest, Wood and Environmental Sciences, 15(1), 9-21.

https://doi.org/10.2478/aslh-2019-0001

Beni, L. H., Villeneuve, S., LeBlanc, D. I., Côté, K., Fazil, A., Otten, A., ... \& Delaquis, P. (2012). Spatio-temporal assessment of food safety risks in Canadian food distribution systems using GIS. Spatial and Spatio-temporal Epidemiology, 3(3), 215-223.

https://doi.org/10.1016/j.sste.2012.02.009

Bilak, A., Caterina, M., Charron, G., Crozet, S., Diaz-Leal, L. R., Foster, F., Ginnetti, J., Giorgi, J., Glatz, A. K, Guyon, K., Howard, C., Kesmaecker-Wissing, M., Kilany., S., Klos,
J., Kok, F., Mccallin, B., Pagot, A., Rushing, E., Spurrel, C., Swain, M., Turner, W., Walicki. N., \& Yonetani, M. (2015). Global Overview 2015: People Internally Displaced by Conflict and Violence' Internal Displacement Monitoring Centre, Norwegian Refugee Council: Geneva.

Burnley, C., Buda, D., \& Kayitakire, F. (2008). Quantitative global model for armed conflict risk assessment. European Commission Joint Research Centre Institute for the Protection and Security of the Citizen Contact. https://doi.org/10.2788/83693

Cai, T., Li, X., Ding, X., Wang, J., \& Zhan, J. (2019). Flood risk assessment based on hydrodynamic model and fuzzy comprehensive evaluation with GIS technique. International Journal of Disaster Risk Reduction, 35, 101077. https://doi.org/10.1016/j.ijdrr.2019.101077

Chen, W., Zhai, G., Fan, C., Jin, W., \& Xie, Y. (2017). A planning framework based on system theory and GIS for urban emergency shelter system: A case of Guangzhou, China. Human and Ecological Risk Assessment: An International Journal, 23(3), 441-456.

https://doi.org/10.1080/10807039.2016.1185692

Chen, W., Zhai, G., Ren, C., Shi, Y., \& Zhang, J. (2018). Urban resources selection and allocation for emergency shelters: In a multi-hazard environment. International Journal of Environmental Research and Public Health, 15(6), 1261. https://doi.org/10.3390/ijerph15061261

Çankaya, Z. C., Süzen, M. L., Yalçıner, A. C., Kolat, C., Zaytsev, A., \& Aytore, B. (2016). A new GIS- based tsunami risk evaluation: MeTHuVA (METU tsunami human vulnerability assessment) at Yenikap1, Istanbul. Earth, $\begin{array}{llll}\text { Planets and } & \text { Space, }\end{array}$ https://doi.org/10.1186/s40623-016-0507-0

Çeliker, M., Yildiz, O., \& Koçer, N. N. (2019). Evaluating solid waste landfill site selection using multi-criteria decision analysis and geographic information systems in the city of Elazığ, Turkey. Pamukkale University Journal of Engineering Sciences, 25(6), 683-691.

https://doi.org/10.5505/pajes.2018.70493

Eccles, K. M., Pauli, B. D., \& Chan, H. M. (2019). The Use of Geographic Information Systems for Spatial Ecological Risk Assessments: An Example from the Athabasca Oil Sands Area in Canada. Environmental Toxicology and Chemistry, 38(12), 2797-2810. https://doi.org/10.1002/etc.4577

Fedeski, M., \& Gwilliam, J. (2007). Urban sustainability in the presence of flood and geological hazards: The development of a GIS-based vulnerability and risk assessment methodology. Landscape and Urban Planning, 83(1), 50-61

https://doi.org/10.1016/j.landurbplan.2007.05.012

Gallego, A., Calafat, C., Segura, M., \& Quintanilla, I. (2019). Land planning and risk assessment for livestock production based on an outranking approach and GIS. Land Use Policy, 83 ,

606-621. https://doi.org/10.1016/j.landusepol.2018.10.02

Gao, C., Gao, C., Song, K., Ye, Z., \& Dong, J. (2019). Regional water ecosystem risk assessment based on GIS and pollutant diffusion model: A case study of Shenzhen eco-industrial park. Process Safety and Environmental Protection, 130, 182-189. https://doi.org/10.1016/j.psep.2019.08.004

Hadipour, V., Vafaie, F., \& Deilami, K. (2020). Coastal Flooding Risk Assessment Using a GIS-Based Spatial Multi-Criteria Decision Analysis Approach. Water, 12(9), 2379. https://doi.org/10.3390/w12092379

Hawchar, L., Naughton, O., Nolan, P., Stewart, M. G., \& Ryan, P. C. (2020). A GIS-based Framework for High-Level 


\section{European Journal of Science and Technology}

Climate Change Risk Assessment of Critical Infrastructure. Climate Risk Management, 100235.

https://doi.org/10.1016/j.crm.2020.100235

Heudtlass, P., Speybroeck, N., \& Guha-Sapir, D. (2016). Excess mortality in refugees, internally displaced persons and resident populations in complex humanitarian emergencies (1998-2012)-insights from operational data. Conflict and health, 10(1), 1-11. https://doi.org/10.1186/s13031-0160082-9

Huabin, W., Gangjun, L., Weiya, X., \& Gonghui, W. (2005). GIS-based landslide hazard assessment: an overview. Progress in Physical Geography, 29(4), 548-567.

https://doi.org/10.1191/0309133305pp462ra

INEE Toolkit - Welcome. (n.d.). Retrieved March 22, 2020, from https://toolkit.ineesite.org/

Isahak, A., Reza, M. I. H., Siwar, C., Ismail, S. M., Sulaiman, N., Hanafi, Z., Zainuddin, M. S., \& Taha, M. R. (2018). Delineating risk zones and evaluation of shelter centres for flood disaster management along the Pahang River Basin, Malaysia. Jàmbá: Journal of Disaster Risk Studies, 10(1), 17. https://doi.org/10.4102/jamba.v10i1.501

Kahraman, C., Öztayşi, B., Sarı, İ. U., \& Turanoğlu, E. (2014). Fuzzy Analytic Hierarchy Process with Interval Type-2 Fuzzy Sets. Knowledge-Based Systems, 59, 48-57. https://doi.org/10.1016/j.knosys.2014.02.001

Karimi, H., Amiri, S., Huang, J., \& Karimi, A. (2019). Integrating GIS and multi-criteria decision analysis for landfill site selection, case study: Javanrood County in Iran. International Journal of Environmental Science and Technology, 16, 7305. https://doi.org/10.1007/s13762-0182151-7

Lyu, H. M., Sun, W. J., Shen, S. L., \& Arulrajah, A. (2018). Flood risk assessment in metro systems of mega-cities using a GIS-based modeling approach. Science of the Total Environment, 626, 1012- 1025.

https://doi.org/10.1016/j.scitotenv.2018.01.138

Mock, N. B., Duale, S., Brown, L. F., Mathys, E., O’Maonaigh, H. C., Abul-Husn, N. K. L., \& Elliott, S. (2004). Conflict and HIV: A framework for risk assessment to prevent HIV in conflict-affected settings in Africa. Emerging Themes in Epidemiology, 1, 1-16. https://doi.org/10.1186/1742-7622$\underline{1-6}$

Öztaysi, B. (2015). A group decision making approach using interval type-2 fuzzy AHP for enterprise information systems project selection. Multiple-Valued Logic and Soft Computing 24: 475-500.

Pence, J., Miller, I., Sakurahara, T., Whitacre, J., Reihani, S., Kee, E., \& Mohaghegh, Z. (2019). GIS-Based Integration of Social Vulnerability and Level 3 Probabilistic Risk Assessment to Advance Emergency Preparedness, Planning, and Response for Severe Nuclear Power Plant Accidents. Risk Analysis, 39(6), 1262-1280. https://doi.org/10.1111/risa.13241

Psomiadis, E., Charizopoulos, N., Efthimiou, N., Soulis, K. X., \& Charalampopoulos, I. (2020). Earth Observation and GISBased Analysis for Landslide Susceptibility and Risk Assessment. ISPRS International Journal of GeoInformation, 9(9), 552. https://doi.org/10.3390/ijgi9090552

Repetto, M. P., Burlando, M., Solari, G., De Gaetano, P., Pizzo, M., \& Tizzi, M. (2018). A web-based GIS platform for the safe management and risk assessment of complex structural and infrastructural systems exposed to wind. Advances in Engineering Software, 117, 29-45.

https://doi.org/10.1016/j.advengsoft.2017.03.002
Rincón, D., Khan, U. T., \& Armenakis, C. (2018). Flood risk mapping using GIS and multi-criteria analysis: A greater Toronto area case study. Geosciences (Switzerland), 8, 275. https://doi.org/10.3390/geosciences8080275

Sahoo, B., \& Bhaskaran, P. K. (2018). Multi-hazard risk assessment of coastal vulnerability from tropical cyclonesA GIS based approach for the Odisha coast. Journal of Environmental Management, 206, 1166-1178. https://doi.org/10.1016/j.jenvman.2017.10.075

Sarkar, S., Parihar, S. M., \& Dutta, A. (2016). Fuzzy risk assessment modelling of East Kolkata Wetland Area: A remote sensing and GIS based approach. Environmental Modelling \& Software, 75, 105- 118.

https://doi.org/10.1016/j.envsoft.2015.10.003

Shalyari, N., Alinejad, A., Hashemi, A. H. G., RadFard, M., \& Dehghani, M. (2019). Health risk assessment of nitrate in groundwater resources of Iranshahr using Monte Carlo simulation and geographic information system (GIS). MethodsX, 6, 1812-1821. https://doi.org/10.1016/i.mex.2019.07.024

Skilodimou, H. D., Bathrellos, G. D., Chousianitis, K., Youssef, A. M., \& Pradhan, B. (2019). Multi-hazard assessment modeling via multi-criteria analysis and GIS: a case study. Environmental Earth Sciences, 78(2), 47. https://doi.org/10.1007/s12665-018-8003-4

Şentürk, E., \& Erener, A. (2017). Determination of temporary shelter areas in natural disasters by gis: A case study, Gölcük/Turkey. International Journal of Engineering and Geosciences, 2(3), 84-90.

https://doi.org/10.26833/ijeg.317314

Török, Z., Petrescu-Mag, R. M., Mereuță, A., Maloș, C. V., Arghiuș, V. I., \& Ozunu, A. (2020). Analysis of territorial compatibility for Seveso-type sites using different risk assessment methods and GIS technique. Land Use Policy, 95, 103878 . https://doi.org/10.1016/j.landusepol.2019.02.037

Uddin, K., Raj, Gurung D., Giriraj, A., \& Shrestha, B. (2013). Application of remote sensing and GIS for flood hazard management: A case study from Sindh Province, Pakistan. American Journal of Geographic Information System, 1, 15.

UNHCR (2019) UNHCR - Internally Displaced People. Retrieved March 22, 2020, from https://www.unhcr.org/pages/49c3646c146.html

Wang, Y., Li, Z., Tang, Z., \& Zeng, G. (2011). A GIS-based spatial multi-criteria approach for flood risk assessment in the Dongting Lake Region, Hunan, Central China. Water Resources Management, 25(13), 3465-3484. https://doi.org/10.1007/s11269-011-9866-2

Yariyan, P., Zabihi, H., Wolf, I. D., Karami, M., \& Amiriyan, S. (2020). Earthquake risk assessment using an integrated Fuzzy Analytic Hierarchy Process with Artificial Neural Networks based on GIS: A case study of Sanandaj in Iran. International Journal of Disaster Risk Reduction, 50, 101705. https://doi.org/10.1016/j.ijdrr.2020.101705

Yu, J. H., \& Lee, S. K. (2012). A conflict-risk assessment model for urban regeneration projects using Fuzzy-FMEA. KSCE Journal of Civil Engineering, 16(7), 1093-1103. https://doi.org/10.1007/s12205-012-1196-2

Zhang, J., Zhai, Y., Xue, P., Huan, H., Zhao, X., Teng, Y., \& Wang, J. (2017). A GIS-based LVF model for semiquantitative assessment of groundwater pollution risk: A case study in Shenyang, NE China. Human and Ecological Risk Assessment: An International Journal, 
23(2), 276-298.

https://doi.org/10.1080/10807039.2016.1245099

Zhang, W., Wu, J., \& Yun, Y. (2019). Strategies for increasing tsunami shelter accessibility to enhance hazard risk adaptive capacity in coastal port cities: A study of Nagoya city, Japan. Natural Hazards and Earth System Sciences, 19(4), 927-940. https://doi.org/10.5194/nhess-19-927-2019

Zhang, D., Shi, X., Xu, H., Jing, Q., Pan, X., Liu, T., ... \& Hou, H. (2020). A GIS-based spatial multi-index model for flood risk assessment in the Yangtze River Basin, China. Environmental Impact Assessment Review, 83, 106397. https://doi.org/10.1016/j.eiar.2020.106397

Zhao, M., \& Liu, X. (2016). Regional risk assessment for urban major hazards based on GIS geoprocessing to improve public safety. Safety Science, 87, 18-24.

https://doi.org/10.1016/j.ssci.2016.03.016

\section{Appendix: Lower Prioritized Risk Maps}

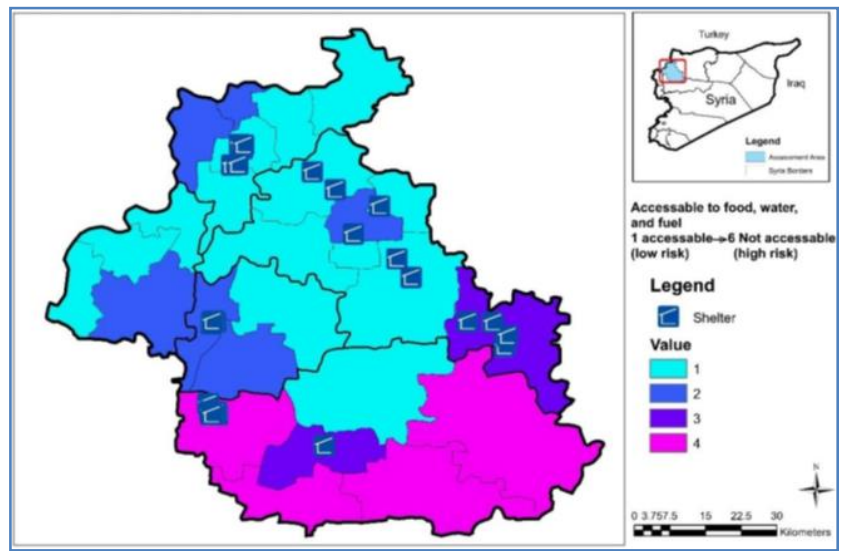

Risk map - accessibility to food, water, and fuel

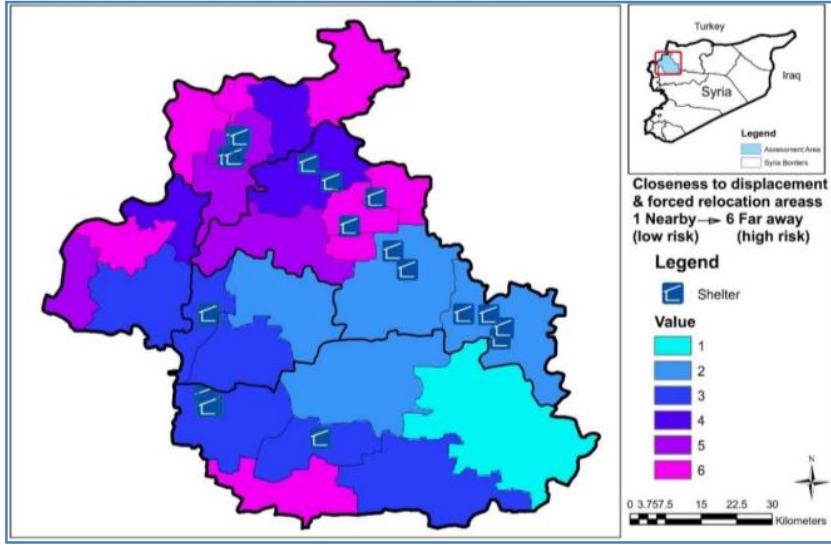

Risk map - proximity to displacement and forced relocation areas

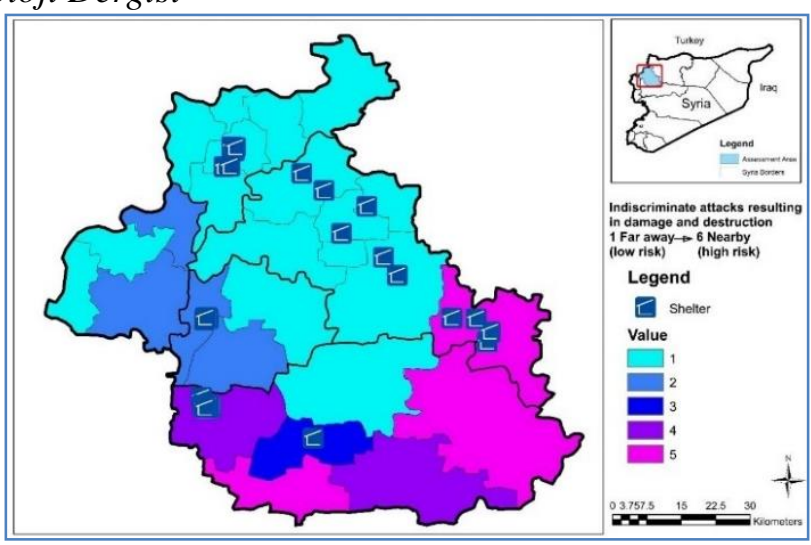

Risk map - indiscriminate attacks resulting in damage and destruction

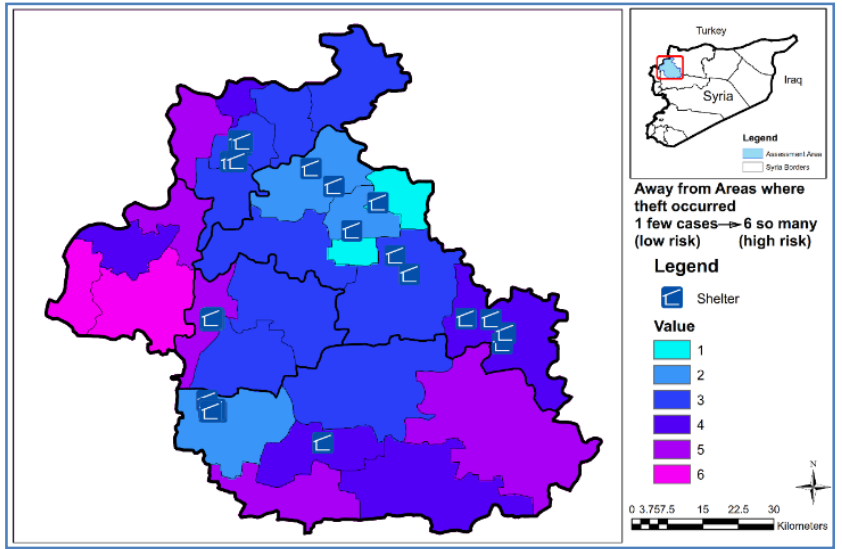

Risk map - away from areas of theft

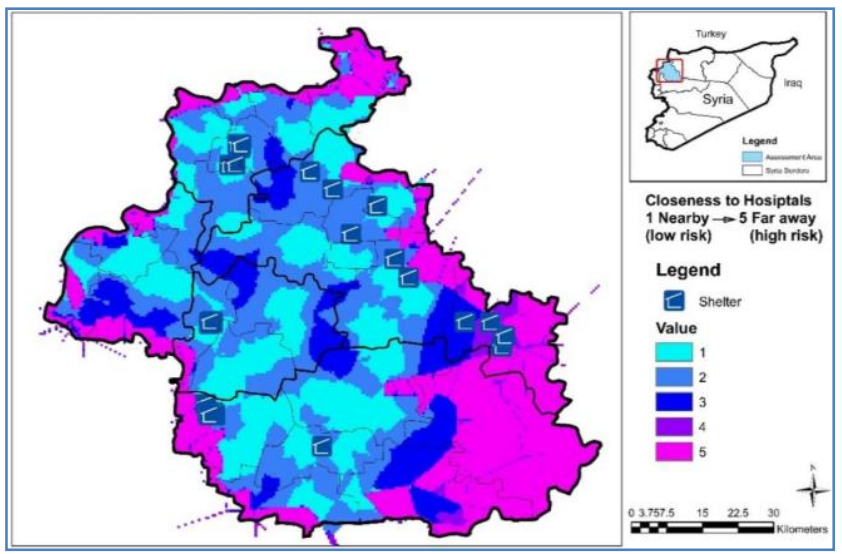

Risk map - proximity to hospitals

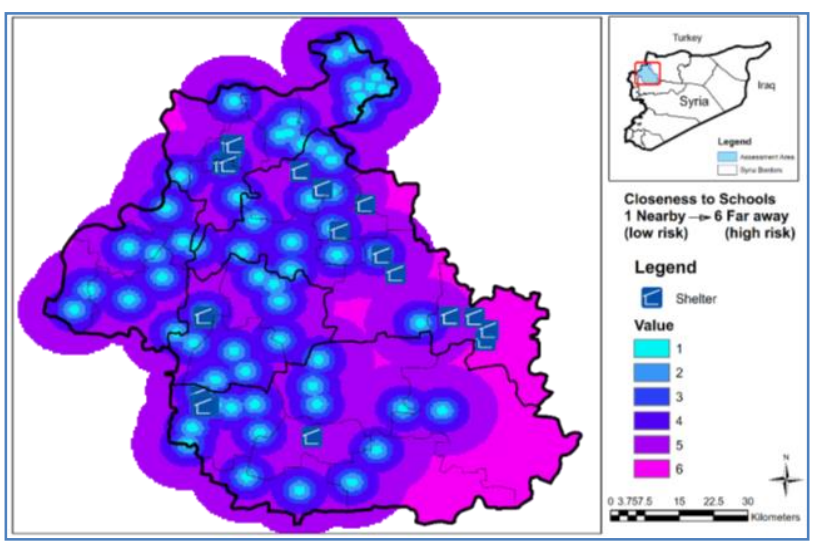

Risk map - proximity to schools 
European Journal of Science and Technology

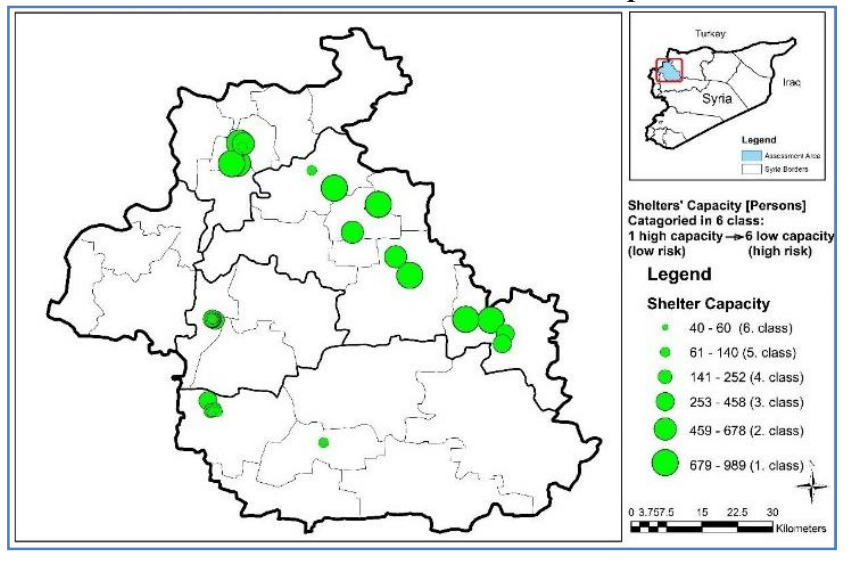

Risk map - shelters' capacity [persons]

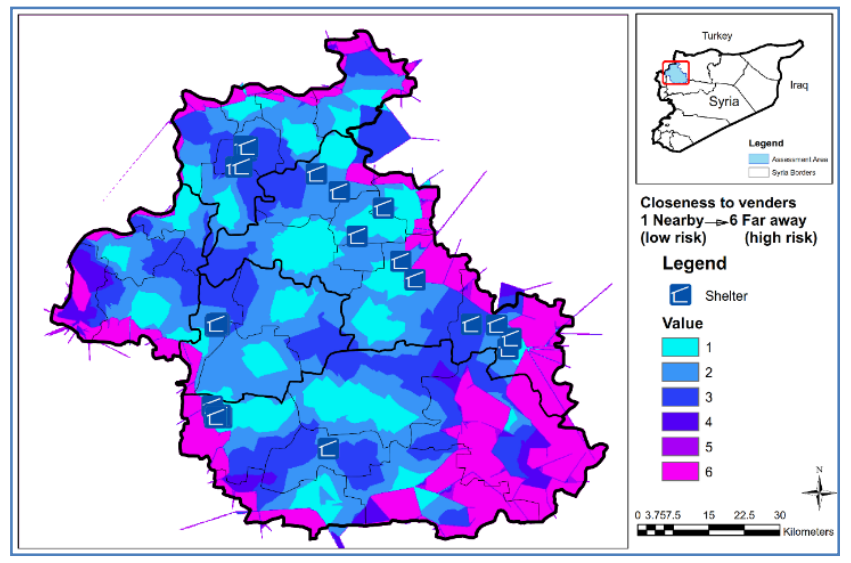

Risk map - proximity to venders/suppliers

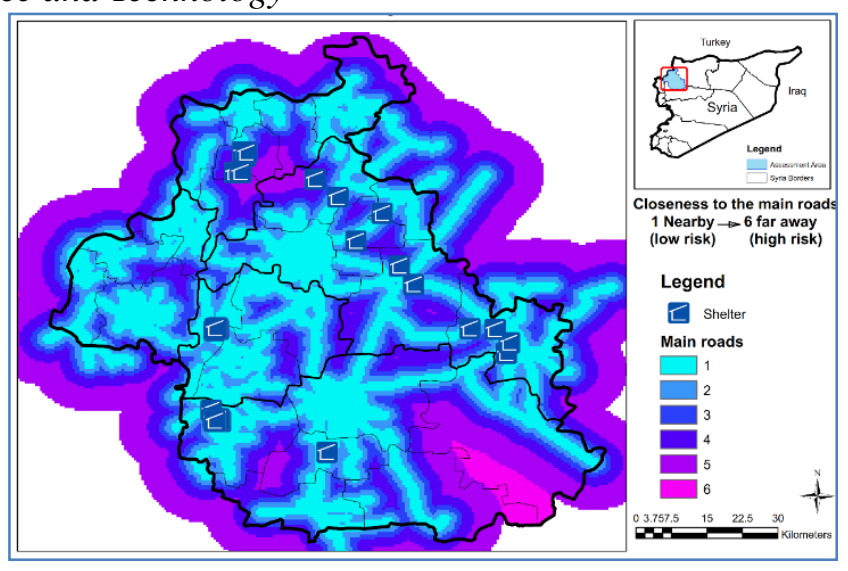

Risk map - proximity to main roads 